\title{
The Informal Sector In Sub-Saharan Africa: Out Of The Shadows To Foster Sustainable Employment And Equity?
}

Donald L Sparks, The Citadel, USA

Stephen T. Barnett, Arizona State University, USA

\begin{abstract}
Over the past twenty years or so, there has been a debate that basically asks ".... whether the informal sector should really be seen as a marginalized, 'survival' sector, which mops up excess or entrenched workers, or as a vibrant, entrepreneurial part of the economy which can stimulate economic growth and job creation." (African Union 2008). This paper argues the latter. Further, this paper argues that employment in the informal sector is no longer a journey, but has become the destination of many. If the aim is to create jobs and reduce poverty, the informal sector must be included in the debate. Indeed, this paper recommends that the debate about the advantages of formal sector vs. the informal sector needs to end. Governments need to unequivocally recognize and admit the importance of the informal sector and finds ways to encourage its growth. They also need, at the same time, to decide how to strengthen the formal sector and extend benefits to those in the informal sector, while removing barriers to the formal sector to allow more to participate. Specifically, there are at least five major areas where changes need to be made: 1) Establish an enabling environment and supportive regulatory framework, 2) Provide access to appropriate training, 3) Improve basic facilities and amenities and infrastructure, 4) Increase ability to obtain property title and access to credit, and 5) Improve national databases and establish uniform standards.
\end{abstract}

Keywords: Informal sector; economic growth; economic development; sustainability; equity; job creation

\section{INTRODUCTION}

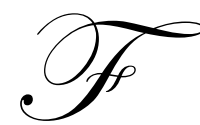

or sub-Saharan Africa, the informal sector is nothing new. Indeed, the types of activities carried out in this sector have existed even prior to colonialism. Later, independence brought in the distinction between informal vs. formal activities as countries around the region sought to formalize or "modernize" their economies. The focus then (and indeed to some degree today) was rapid industrialization. Now, for much of the region, it is the informal sector - not the formal sector - that is the growth engine. It should be noted that around the world, about two-thirds of all employees work in the informal sector (World bank 2009). Thus, how governments treat the informal sector has profound impacts on employment, growth, equity and sustainability.

Over the past twenty years or so, there has been a debate that basically asks "... whether the informal sector should really be seen as a marginalized, 'survival' sector, which mops up excess or entrenched workers, or as a vibrant, entrepreneurial part of the economy which can stimulate economic growth and job creation." (African Union 2008). This paper argues the later. Further, this paper argues that employment in the informal sector is no longer a journey, but has become the destination of many. If the aim is to create jobs and reduce poverty, the informal sector must be included in the debate.

The informal sector represents the dominant share of many sectors across the continent, especially in manufacturing, commerce, finance and mining. Trade-related activities, including street vending, is the most common form of activity in Africa's informal sector. The informal sector provides between $50-75 \%$ of employment 
(Haan 2006), and 72\% of non-agricultural employment, $78 \%$ if South Africa is excluded (African Union 2008, ILO $2002 \mathrm{~b}$, Verick 2008). The sector comprised an average of $42 \%$ of Gross National Income (GNI) in 2000, ranging from under 30\% in South Africa to 60\% in Tanzania and Nigeria (Verick 2008, Schneider 2002). Chen estimated that $93 \%$ of new jobs created in sub-Saharan Africa during the 1990s were in the informal sector (Chen 2001). Indeed, informal sector employment in Uganda and Kenya now exceeds employment in the formal sector and nearly 90\% of the labor force in Ghana comes from the informal sector (African Union 2008).

Nonetheless, in many countries this sector remains in the shadows of the formal economy (Ihrig, J. and K.S. Moe (2004), Schneider, F. and R. Klingrnair (2004), Schneider (2007). Additionally, firms in the informal sector "...typically grow more slowly, have poor access to credit and employ fewer workers, and their workers remain outside the protection of labor law." (World Bank 2009). Indeed, in many instances the authorities are outright hostile to the informal sector, closing down operations without warning. Such hostility is in large part prompted by the fear of competition by those in the formal sector. The formal sector generally is where the political clout resides. Informal enterprises are therefore forced to remain "in the shadows" or pay bribes to remain in operation. In addition, the fear of being closed down discourages investment in better facilities, and the constant moving results in inefficiencies. Of course all of this has serious implications for employment.

This paper will examine the causes for the dramatic growth of sub-Saharan Africa's informal sector, the implications for growth, employment and equity, and will offer some recommendations to help elevate the informal sector as a true engine of growth and sustainability.

\section{THE GROWTH OF THE INFORMAL SECTOR IN SUB-SAHARAN AFRICA}

The informal sector was "discovered" in the early 1970s (Bangasser 2000, ILO 2002, Adams 2004, Haan 2006, Fox and Gaal 2008). In 1972 the ILO suggested that the informal sector is, "the non-structured sector that has emerged in the urban centres as a result of the modern sector's inability to absorb new entrants..." (ILO 1972). In 1997 the ILO expanded the definition to, “...private unincorporated enterprises which produce at least some of their goods and services for sale or barter, have less than 5 paid employees, are not registered, and are engaged in nonagricultural activities including professional or technical services (ILO 2002a). However, it was not until 1993 that the ILO provided a statistical definition of the informal sector. The "resolution concerning statistics of employment in the informal sector" adopted by the $15^{\text {th }}$ International Conference of Labour Statistics in January 1993 suggested, "The informal sector may be broadly characterized as consisting of units engaged in the production of goods or services with the primary object of generating employment and incomes to the persons concerned...".

Further, until 2002 there were no continent-wide, agreed-upon criteria on measuring the informal sector, so it is difficult to make cross-continental comparisons prior to that date. Indeed, the ILO allowed great flexibility in the definition of the informal sector. Agricultural activities were excluded in some countries' surveys, while included in others. For example, while Mali shows $90 \%$ of its workers in the informal sector, this is because it includes the agricultural sector (Devey, Skinner and Valodia 2006). Also, many countries have not even collected data on the informal sector (African Union 2008).

Nonetheless, some general characterizations can be made about the causes of the informal sector's growth in recent years. They include:

\section{Urban Bias and Labor Laws}

Lipton (1977) argued that many African leaders pursued development policies that had at their heart an urban bias, as the city was where the power base generally lay. Such leaders devoted the vast majority of resources toward urban development, to the determinant of rural areas. In addition, most international development agencies and international financial institutions vastly favored supporting projects in urban areas, as they were easier to monitor and reinforced political goodwill to the leadership. All of this had several effects, one of the most telling was to provide a "bright light" to rural dwellers who sought what they believed would be improved health, education and employment conditions. However, cities were unable to offer sufficient jobs to satisfy the vast numbers trying to enter into the formal sector. 
Urban labor laws have been a major factor in the growth of the informal sector (Schneider and Klinhmair 2004). For example, legislated minimum wage laws have acted as a break toward firms trying to expand and move into the formal sector. There are other costs as well, and as these costs add up they further deter entry into the formal sector.

\section{Rural-Urban Migration}

Policies of urban bias had other effects as the migration from rural areas to urban areas increased, secondary school education, while once an assurance of a state job, became less and less guaranteed, and many secondary school leavers have found themselves in the informal sector. Sethuraman (1997) found significant movements of unemployed (especially young people) from rural to urban areas of war torn Mozambique and Angola in the 1980s, resulting in increased work in the informal sector as the formal sector did not have sufficient jobs available.

\section{Structural Adjustment Policies}

There is a growing literature on the relationship between the Structural Adjustment Policies (SAPs) of the 1980s and 1990s and the growth of the informal sector (Lee and Viuvarelli 2004). These SAPs (often at the insistence of the International Monetary Fund and others) usually required cutbacks in government spending and public sector downsizing in general, resulting in increased unemployment in the formal sector. Often such cutbacks induced even those in the government sector to find an additional job, almost always in the informal sector. A good example comes from Kenya, where Ikiara and Ndung'u (1999) suggest that the SAPs caused the employment rate in the informal sector to increase from about $4 \%$ in the 1970 s to about $50 \%$ by 1994 .

\section{Difficulty in Establishing New Firms}

According to the World Bank, "Where regulation is particularly onerous, levels of informality are higher." (World Bank 2009). Of all the regions of the world, sub-Saharan Africa ranks highest in the number of procedures and days (63) required to establish a new business. There are on average 20 licensing procedures to build a warehouse and it takes on average 251 days to obtain a business license, higher than anywhere else other than Eastern Europe. Of all the world's regions, sub-Saharan Africa ranks last on the World Bank's Most Friendly Business Regulations list (World Bank 2009).

During the past ten years or so many governments in the region began to make reforms with the intent to streamline and simplify the mechanics of starting up a new business. It should be noted that of the top ten "reformers" in 2008/09, six were from sub-Saharan Africa. Indeed, Rwanda led the list (the first time for a country from the region). Significantly, it passed two new laws that greatly facilitated bankruptcy laws and new business registration. Nevertheless, as the World Bank has noted, the region lags far behind the rest of the world in providing a business-friendly enabling environment (World bank 2009).

\section{Peace and the Demobilization of Military}

Where peace comes to a country, the military is usually demobilized, at least to a degree. For example, Ethiopia released over 540,000 soldiers between 1991 and 1995, without offering formal sector jobs; indeed, the government actually reduced public sector employment (Haltiwanger and Singh 1999).

\section{IMPLICATIONS FOR SUSTAINABLE EMPLOYMENT AND EQUITY}

Of major concern to policy-makers in the region is employment creation. They generally want to expand the formal sector and have often ignored the informal sector (due in many respects to the urban bias policies addressed above). One can perhaps better understand this issue by breaking down the informal economy into type of enterprise and type of employment (see Table 1). 
Table 1: The Informal Sector in Sub Saharan Africa

\begin{tabular}{ll}
\hline Type of Informal Enterprise & Type of Informal Job \\
\hline Scale & Part-time \\
Location & Seasonal \\
Modes of production & Full-time \\
Ownership & Managerial \\
Output/activity & \\
\hline
\end{tabular}

The informal enterprises themselves may be legal or extra legal, may or may not pay taxes, are not formally incorporated in a legal sense, usually (but not always) small scale with under 5 workers, owned by individuals, with management decisions made by the owners and all assets and liabilities assumed by the proprietors. Becker (2004) estimates that nearly $3 / 4$ of workers in the informal sector are self-employed. The start up costs of informal enterprises are usually low.

Employment in the sector is varied, and generally the firms are labor intensive. Often work is seasonal (especially in agriculture) or part time. At one extreme is the entrepreneur, usually the owner, followed by (often unpaid) family members and neighbors. There is no tenure, often little or no protection from the state and no safety nor social equity safety nets such as job security, unemployment benefits or health care. Nonetheless, average incomes are often higher --on average by 50\%-- than incomes in the agricultural sector (Fox and Gaal 2008), although wages are on average 44\% lower than jobs found in the formal sector (ILO 2002a). Workers in the informal sector often receive remittances from relatives in the African Diaspora (Verick 2008). And, while educational levels are generally lower than those found in the formal sector --37\% of workers in South Africa's informal economy had not completed primary school, compared to only $16 \%$ in the formal sector-- that is changing as more and more educated workers find their way into the informal sector (Verick 2008). Most workers -perhaps as many as 70\%-- received their training through apprenticeships, especially in the urban areas (Liimataien 2002, Haan 2006, Filipiak 2007). Women make up the majority of informal workers in many urban areas; for example Charles (1998a) estimated that $75 \%$ of street vendors in Benin were women. Women are usually self-employed and homebased. Workers in the informal sector generally work longer hours (El Mahdi and Amer 2005). Child labor remains a problem (Xaba, et al. 2002).

The labor market presents a classic example of a potential trade off between worker equity and efficiency. While governments want to set an enabling environment that creates more jobs, for example by allowing greater hiring and firing flexibility, they also want to provide for increased social protections, such as minimum wages. However, that could make job creation more difficult.

There is criticism that the informal sector is unproductive since it doesn't often utilize the most recent technology, is small scale, etc. However, Gelb et al (2009) found that the "...productivity of individual firms is virtually indistinguishable from that of formal firms in East Africa..." (although that was not the case they found in southern Africa).

The linkages with the formal sector should be noted. The UN's "Informal Sector Development in Africa" report (UN 1996) suggests five major linkages:

1. Forward linkages: where firms in the formal sector buy inputs from those produced in the informal sector.

2. Backward linkages: where formal sector firms supply inputs to those in the informal sector (e.g., communications technology).

3. Technology linkages: transferring technology from one sector to the other.

4. Consumer linkages: people from all sectors buy final products (goods and services) from the informal sector.

5. Credit linkages: Often the informal sector obtains credit from the formal sector. 
Globalization can also affect the informal sector and amplify those linkages. The world's economic slump of the past year has made starting businesses even more difficult. For example, getting finance became much more difficult, global trade contracted and demand for primary products dropped. In addition, because of income inelasticities of demand, consumers in the developed world do not increase consumption of agricultural products at the same rate as their incomes increase. This is a particular problem for sub-Saharan Africa as for many countries agricultural commodities constitute as much as $80 \%$ of their exports. In other words, the agricultural sector does not provide additional jobs, and those living in rural areas seek jobs in the cities and towns, exacerbating the already over-supply of labor found there.

Governments often provide incentives for attracting foreign investment, and this can all too often result in a race to the bottom, which in turn can accentuate income inequalities, as foreign investment is usually associated with the formal sector. Also, when the formal sector contracts due to an economic downturn, increased import competition, slackened demand, etc, then the informal sector is hurt via the forward linkage described above.

\section{CONCLUSIONS AND RECOMMENDATIONS}

This paper concludes with the recommendation that the debate about formal/informal dualism needs to end. Governments need to unequivocally recognize and admit the importance of the informal sector and find ways to encourage its growth. They also need at the same time to decide how to strengthen the formal sector and extend benefits to those in the informal sector, while removing barriers to the formal sector to allow more to participate. Specifically, there are at least five major areas where changes need to be made:

1. Establish an Enabling Environment and Supportive Regulatory Framework

Organize informal workers where appropriate and feasible. While traditional unions are not likely to accommodate workers in the informal sector, there are a range of options open (Verick 2008). For example, grassroots organizations can represent informal enterprises and lobby on their behalf. Purchasing associations can garnish their buying power to pressure for better deals for members. In addition, worker representation, while perhaps informal, can inform policy makers about concerns of the informal sector. The Self-Employed Women's Association in Kenya is a good example of such a grass roots worker organization (Chen and Carr 2004). In addition, a good enabling environment would include reducing official harassment of the informal sector, and offer ways to protect those enterprises and workers.

\section{Provide Access to Appropriate Training}

Formal education does not suit the needs of informal workers, and it is not flexible enough. However, vocational and other types of education aimed at the informal sector is sometimes known as "second-chance education" (Adams 2007). Governments need to help change that attitude. Specifically, leaders should push for more literacy programs including training vouchers. Informal education programs should provide instruction in the evenings and weekends. Programs should stress entrepreneurship and strengthen apprenticeships with subsidies. For example, Haan and Serriere (2002) estimate that apprenticeships fees average US\$70 annually, while Palmer (2007) found that in Ghana the average was US $\$ 42$.

\section{Improve Basic Facilities and Amenities and Infrastructure}

Since workers in the informal sector generally do not pay taxes, they are not eligible for many social benefits. It is possible to offer cascading levels of health and retirement benefits given the political willpower. A good example could be found in Tanzania, where the ILO helped create an umbrella organization to provide health care. By 1999 the "Mutual Society for Health Care in the Informal Sector" had nearly 2,000 members each contributing US $\$ 2$ per month into the system (ILO 2002a). 
4. Increase Ability to Obtain Property Title and Access to Credit

Because of the lack of title and other proof of ownership of assets, informal sector enterprises often are unable to get loans because of lack of collateral (DeSoto 2000). Without such collateral, lenders generally insist on much higher interest rates, making it difficult for informal sector entrepreneurs to obtain the necessary financing for either initiating new enterprises or expanding existing ones. This is a hindrance in being able to obtain newer, more efficient technologies. Such technologies can be critical. For example, internet access can allow sellers, particularly when producing agricultural commodities, more up-to-date prices and types of information --such as commodity prices and weather forecasts-- that in the past was difficult to come by. Due to the high cost of land lines, subSaharan Africa has used "leapfrog technology" in developing a significant mobile phone network which is being used for a variety of commercial purposes, including distance banking (Sparks 2008). Shared cell phone shops are an inexpensive way to widen access to this technology. Also, most informal enterprises have little or no access to insurance, making them subject to variances in the weather and market forces. Insurance schemes for informal sector enterprises should be subsidized and expanded. Property rights are important also to provide information that can be used by other or potential buyers or sellers.

5. Improve National Data Bases and Establish Uniform Standards

Due to very nature of the formal sector, many times statistics are not reported. Governments need to find ways that allow informal sector firms to report data without fear of reprisals. As noted earlier, many countries lack satisfactory statistical offices, and even where such agencies exist there are conflicting standards about specific activities of the informal sector. The African Union should spearhead an effort to support strengthening such activities.

\section{AUTHOR INFORMATION}

Donald L Sparks, PhD is Professor of International Economics at The Citadel in Charleston, South Carolina, USA. He received his BA from the George Washington University and his MA and PhD from the School of Oriental and African Studies of the University of London. He ahs received three Fulbright Scholar awards. Before coming to the Citadel Dr Sparks was Regional Economist for Africa at the US Department of State.

Stephen T. Barnett, PhD is Director of Student International Advancement at Arizona State University in Tempe, Arizona, USA. He received his BA from the University of Georgia and his MA and PhD from Georgia Southern University. Prior to coming to Arizona State, Dr Barnett was Professor of Marketing at Stetson University and directed its summer Innsbruck Business Program for 10 years.

\section{REFERENCES}

1. Adams, Arvil V (2007). "The Role of Youth Skills Development in the Transition from School to Work: A Global Review", HDNCY Discussion Paper No. 5, Washington, DC: World Bank.

2. African Union (2008). "Study on the Informal Sector in Africa". Sixth Ordinary Session of the Labor and Social Affairs Commission of the African Union, Addis Ababa.

3. Almeida, Rita and Carneiro, Pedro Manuel. 2005. "Enforcement of Labor Regulation, Informal Labor, and Firm Performance." World Bank Policy Research Working Paper No. 3756. Washington, DC: World Bank.

4. Aryee, G.A. (2002). "Policy Design for the Promotion of Employment and Incomes in the Informal Economy: the Need for Labour Market Information," Paper presented at the Workshop on Making Good Use of Labour Market Information, Windhoek.

5. Atchoarena, David and Andre Marcel Delluc (2001). "Revisiting Technical and Vocational Education in Sub-Saharan Africa: An Update on Trends, Innovations, and Challenges”, IIEP/Prg.DA/1,320. Paris: International Institute for Educational Planning.

6. Atchoarena, David and Paul Esquieu (2002). "Private Technical and Vocational Education in Sub-Saharan Africa: Provision Patterns and Policy Issues”. International Institute for Educational Planning, Paris. 
7. Aterido, Reyes, Mary Hallward-Driemeier and Carmen Pages (2007). "Investment Climate and Employment Growth: The Impact of Access to Finance, Corruption and Regulations Across Firms". IZA Discussion Paper No. 3138.

8. Avirgan, T., Bivens, L.J. and S. Gammage (eds.) (2005). “Good Jobs, Bad Jobs, No Jobs - Labor Markets and Informal Work in Egypt, El Salvador, Rurria, and South Africa”. Economic Policy Institute, Washington, DC.

9. Bangasser, Paul (2000). "The ILO and the Informal Sector: An Institutional History," ILO Employment Paper 2000/9, Geneva.

10. Becker, K.F. (2004). "The Informal Economy", SIDA Report, March 2004.

11. Becker, Kristina Flodman (2004). "The Informal Economy." A fact finding study prepared for the Swedish International Development Agency, Stockholm.

12. Bennell, Paul (1999). "Learning to Change: Skills Development Among the Economically Vulnerable and Socially Excluded in Developing Countries." ILO Employment and Training Department. Geneva.

13. Biggs, Tyler, Manju Shah, Pradeep Srivastava (1995). "Technological Capabilities and Learning for African Enterprises," Technical Paper No. 288, African Technical Department Series. Washington D.C.: World Bank.

14. Boateng, K. (1998). "Quality jobs or mass employment," African Economic Research Consortium Research Paper, No.98.

15. Braude, W. (2005). "South Africa: Bringing Informal Workers into the Regulated Sphere, Overcoming Apartheid's Legacy," Avirgan et al. (eds.).

16. Brewer, Laura (2004). "Youth at Risk: The Role of Skills Development in Facilitating the Transition to Work." ILO Skills Working Paper \#19, Geneva.

17. Canales, A. (2003). "Mexican labour migration to the United States in the age of globalization," Journal of Ethnic and Migration Studies, Vol.29, No.4, pp.741-761.

18. Carr, M. and M.A. Chen (2002) "Globalization and the informal economy: how global trade and investment impact on the working poor," ILO Employment Sector Working Paper on the Informal Economy, No.2002/1.

19. Charmes, J. (1998a). "Women Working in the Informal Sector in Africa: New Methods and New Data," Paper prepared for the UN Statistics Division, the Gender in Development Programme of UNDP, and the project "Women in Informal Employment: Globalizing and Organizing".

20. Charmes, J. (1998b). "Street Vendors in Africa: Data and Methods," Paper prepared for the UN Statistics Division, the Gender in Development Programme of UNDP, and the project "Women in Informal Employment: Globalizing and Organizing".

21. Chen, M.A. (2001). "Women in the Informal Sector: a Global Picture, the Global Movement", SAIS Review, Winter-Spring 2001.

22. Chen, M.A. and Marilyn Carr (2004). "Globalization, Social Exclusion and Work: With Special Reference to Informal Employment and Gender." International Labour Review: Special Issue on More Equitable Globalization, Vol. 143, Nos. 1-2, Geneva: ILO.

23. Chen, M.A. and Marilyn Carr (2002a). "Globalization and the Informal Economy: How Global Trade and Investment Impact on the Working Poor". Working Paper on the Informal Economy, No. 1. Geneva : ILO.

24. Chen, M.A., Jhabvala, R. and F. Lund (2002b). "Supporting Workers in the Informal Economy: a Policy Framework", ILO Employment Sector Working Paper on the Informal Economy, No. 2002/2.

25. Chen, M.A., Sebstad, J. and L. O'Connell (1999). "Counting the Invisible Workforce: the Case of Home-based Workers," World Development, Vol.27, No.3, pp.603-610.

26. Dar, Amit, Sudharshan Canagarajah, Paud Murphy (2003). "Training Levies: Rationale and Evaluation from Evaluations,"http://siteresources.worldbank.org/INTLM/Resources/TrainingLevies.pdf. Washington, D.C: World Bank.

27. De Paulo, Aureo, Jose A Scheinkman (2007). "The Informal Sector, Second Version". PIER Working Paper No. 07-035.

28. De Soto, H. (2000). The Mystery of Capital: Why Capitalism Triumphs in the West and Fails Everywhere Else. New York:Basic Books,.

29. Devey, Richard, Caroline Skinner, Imraan Valodia (2006). "Second Best? Trends and Linkages in the Informal Economy in South Africa." School of Development Studies, University of KwaZulu Natal, Working Paper 06/102. Durban. 
30. Djankov, Simeon, Ira Lieberman, Joyita Mukherjee and Tatiana Nenova (2002). "Going Informal: Benefits and Costs" in Boyan Belev, editor. The Informal Economy in the EU Accession Countries. Center for the Study of Democracy.

31. El-Mandi, A. and M. Amer (2005). "Egypt: growing informality, 1990-2003," in Avirgan et al. (eds.) (2005).

32. Emery, James in Nicole Ball, Nicolas van de Walle and Vijaya Ratnachanchan (eds.) (2003). Beyond Structural Adjustment: the Institutional Context of African Development. London: Palgrave Macmillan.

33. Emran, M. Shahe and Joseph Stiglitz (2004). "Price-neutral Tax Reform. Within the Informal Economy". Manuscript.

34. Fafchamps, Marcel (1994). "Industrial Structure and Micro-Enterprises in Africa." Journal of Developing Areas, 29(1):1-30.

35. Fajnzylber, Pablo, William Maloney and Gabriel Rojas (2005). "Releasing Constraints to Growth or Pushing on a String? The Impact of Credit, Training, Business Associations and Taxes on the Performance of Mexican Micro Firms", World Bank Working Paper \#2807.

36. Farstad, Halfdan (2002). "Integrated Entrepreneurship Education in Botswana, Uganda, and Kenya: Final Report." National Institute of Technology, Oslo.

37. Filipiak, Ewa (2007). "Vocational Training in the Informal Sector: the Outcomes of a Field Survey in Seven African Countries." A Powerpoint presentation prepared by the Research Department, Agence Francaise de Developement, Paris.

38. Fortin, Bernard, Guy Lacroix, and Claude Montmarquette (1997). "Are Underground Workers More Likely to be Underground Consumers?" Cahiers de Recherche, Universite Laval.

39. Fosu, A.K. (2002). "International trade and labour market adjustment in developing countries," Chapter 8, in Greenaway, G., Upward, R. and K. Wakel (2002) Trade, Investment, Migration and Labour Market ArOftment, Palgrave Macmillan, New York.

40. Fosu, A.K. (2004). "The Social Impact of Globalization," in Lee, E. and M. Vivarelli (eds.) (2004) Understanding Globalization, Employment and Poverty Reduction, Palgrave Macmillan, New York.

41. Fox, Louise and Ana Maria Oviedo (2008). "Are Skills Rewarded in Sub-Saharan Africa? Determinants of Wages and Productivity in the Manufacturing Sector," World Bank Policy Research Working Paper 4688.

42. Fox, M. Louise and Melissa Sekkel Gaal (2008). "Working Out of Poverty," Africa Region, World Bank, Washington, D.C.

43. Gatti, Roberta and Maddalena Honorati (2008). "Informality among Formal Firms: Firm-level, Crosscountry Evidence on Tax Compliance and Access to Credit." World Bank Policy Research Working Paper 4476.

44. Gelb, Alan, Taye Mengistae, Vijaya Ramachandran, and Manjua Kedia Shah (2009). "To Formalize or Not to Foramilze? Comparisons of Micro-enterprise Data from Southern and East Africa". Center for Global Development, Working Paper 175, Canbera, Australia.

45. Gerxhani, Klarita (2004). The Informal Sector in Developed and Less Developed Countries: A Literature Survey", Public Choice, Volume 120, Number 3.

46. Gill, Indermit, Fred Fluitman, and Amit Dar (eds) (2000). "Vocational Education and Training Reform: Matching Skills to Markets and Budgets". World Bank and ILO. Washington, D.C. and Geneva.

47. Goldberg, P.K. and N. Pavcnik (2003). "The Response of the Informal Sector to Trade Liberalization," Journal of Development Economics, Vol.72, pp.463-496.

48. Haan, Hans Christiaan (2006). "Training for Work in the Informal Micro-Enterprise Sector: Fresh Evidence from Sub-Sahara Africa". Unesco-Unevoc, Springer, The Netherlands.

49. Haltiwanger, J. and M. Singh (1999). "Cross-country evidence on public sector retrenchment," World Bank Economic Review, Vol.13, No.1, pp23-66.

50. Harsch, E. (2001). "Making trade work for poor women," Africa Recovery, Vol.15, No.4, p.6.

51. Hirosato, Yaushi (1997). "Skills Development Fund: a Preliminary Assessment of a Financing Alternative for Enterprise-Based Training in the Context of APEC," GSID APEC Discussion Paper No. 17. Nagoya, Japan.

52. Hussmanns, Ralf (2004). "Measuring the Informal Economy: From Employment in the rnformar Sector to Informal Employment." ILO Working Paper No. 53, ILO Bureau of Statistics, Geneva.

53. Ihrig, J. and K.S. Moe (2004). "Lurking in the Shadows: the Informal Sector and Government Policy." Journal of Development Economics. 
54. Ikiara, G.K. and N.S. Ndung'u (1999). "Kenya", in van der Geest, W. and R. van der Hoeven (eds.) (1999) Adjustment, Employment \& Missing Institutions in Africa, ILO, Geneva, and James Currey Ltd, Oxford.

55. International Labour Office (1972). Employment, Incomes and Equality: A Strategy for Increasing Productive Employment in Kenya, ILO, Geneva.

56. International Labour Office (2002a) "Decent work and the informal economy," Report of the Director-General, International Labour Conference, $90^{\text {th }}$ Session, Report VI, ILO, Geneva.

57. International Labour Office (2002b) "ILO compendium of official statistics on employment in the informal sector," STAT Working Paper, 2002 - No.1.

58. International Labour Office (2002c) "Women and Men in the Informal Economy: A Statistical Picture", ILO, Geneva.

59. International Labour Office (2002d). "Decent Work and the Informal Economy: Abstracts of Working Papers," ILO Employment Sector, Geneva.

60. International Labour Office (2006). "Vocational Training in the Informal Sector: Report on the Morocco Field Survey," Working Paper No. 16, Department of Research, Agence Francaise de Developement, Paris.

61. Ishengoma, Esther and Robert Kappel. 2006. "Economic Growth and Poverty: Does Formalisation of Informal Enterprises Matter?" German Institute of Global and Area Studies (GIGA) Working Paper No. 20.

62. Johanson, Richard and Arvil V. Adams (2004). Skills Development in Sub-Saharan Africa. Regional and Sectoral Studies, Washington, D.C.: World Bank.

63. Johnson, Simon, Daniel Kaufmann, Pablo Zoido (1998). "Regulatory Discretion and the Unofficial Economy." AER, Vol. 88, No. 2.

64. Kaufmann, Daniel, Aart Kraay, and Massimo Mastruzzi (2008). "Governance Matters V: Aggregate Individual Governance Indicators for 1996-2005". World Bank Policy Research Working Paper No. 4012.

65. Krishnan, P., Selassie, T.G. and S. Dercon (1998). "The Urban Labour Market During Structural Adjustment: Ethiopia 1990-1997," CSAE Working. Paper, WPS/98-9.

66. La Porta, Rafael and Andrei Shleifer (2008). "The Unofficial Economy and Economic Development," Manuscript.

67. Lecuyer, N. (ed.) (2002) New Forms of Labour Administration: Actors in Development, ILO, Geneva.

68. Lee, E. and M. Vivarelli (eds.) (2004). Understanding Globalization, Employment and Poverty Reduction, New York: Palgrave Macmillan.

69. Lewis, W.A. (1954). "Economic Development with Unlimited Supplies of Labour," Manchester School, Vol.22(May), pp.139-191.

70. Liimatainen, Marjo-Riita (2002). "Training and Skills Acquisition in the Informal Sector: A Literature Review." ILO InFocus Programme on Skills, Knowledge and Employability, Geneva.

71. Lipton, M (1977). Why Poor People Stay Poor: Urban Bias in World Development. Boston: Harvard University Press.

72. Loayza, Norman V, Ana Maria Oviedo, and Luis Serven (2005). "The impact of regulation on growth and informality - cross-country evidence." Policy Research Working Paper Series 3623. Washington, DC:

World Bank.

73. Lucas, Robert (1978). "On the Size Distribution of Business Firms". Bell Journal of Economic's Autumn, Volume: 9, Issue: 2, pp. 508-523.

74. Lund, Francie and Caroline Skinner (2003). "The Investment Climate for the Informal Economy: A Case of Durban, South Africa." School of Development Studies, University of Natal, Durban.

75. Maldonado, C. (1995). "The informal sector: Legalization or Laissez-faire?" International Labour Review, Vol.134, No.6, pp.705-728.

76. Marcouiller, D. and Young, L. (1995). "The Black Hole of Graft: The Predatory State and the Informal Economy." American Economic Review. 1995

77. Marjit, S. and D.S. Main (2005). "Globalization, Reform and the Informal Sector," WIDER Research Paper, No.2005/12.

78. McGrath, Simon and Kenneth King with others (1994). "Education and Training for the Informal Sector." U.K. Department for International Development, Education Research Paper 11, London.

79. Monk, Courtney, Justin Sandefur, and Francis Teal (2007). "Apprenticeship in Ghana,""Centre for the Study of African Economies, Department of Economics, University of Oxford, (processed). 
80. Mupedziswa, R. and P. Gumbo (2001). "Women Informal Traders in Harare and the Struggle for Survival in an Environment of Economic Reforms," Nordiska Afrikainstitutet Research Report, No.117.

81. Nicolas Serriere (2002). "Training for Work in the rnformar Sector: Fresh Evidence from West and Central Africa. ILO Occasional Papers, Turin.

82. Nielson, Helena Skyte, Michael Rosholm, and Andrew Dabalen (2007). "Evaluation of Training in African Enterprises," Journal of Development Economics.

83. NISER (2007). "Report of Baseline Study of Employment Generation in the Informal Sector of the Nigerian Economy." Prepared by the Nigerian Institute of Social and Economic Research for the Africa Capacity Building Foundation and the ILO. Ibadan.

84. North, D.C. and R. Thomas (1973). The Rise of the Western World: A New Economic History, Cambridge University Press, Cambridge.

85. OECD (1999) "Employment Protection and Labour Market Performance," In OECD Employment Outlook, pp. 45-132, OECD, Paris.

86. OECD (2004) "Employment Protection Regulation and Labour Market Performance," In OECD Employment Outlook, pp. 61-125, OECD, Paris.

87. Oxenham, John, Abdoul Hamid Dialoo, Anne Katahoire, Anna Petrovika-Mwangi, and Oumar Sall (2002). "Skills and Literacy Training for Better Livelihoods: A Review of Approaches and Experiences." Africa Region Human Developmet Working Paper Series. Washington, D.C.: World Bank.

88. Palmer, Robert (2007a). Skills Development, the Enabling Environment and Informal Micro-Enterprise in Ghana, doctoral thesis (mimeo), Edinburgh: University of Edinburgh.

89. Ramachandran, Vijaya and Manju Kedia Shah (2006). "Why Are There So Few Black-Owned Firms in Africa? Preliminary Results from Enterprise Survey Data". Working Paper 104. Center for Global Development.

90. Rauch, James E. (1991). "Modelling the informal sector formally," Journal of Development Economics. Elsevier, vol. 35(1), pages 33-47, January.

91. Riley, Thyra A. and William F. Steel (2000). "Kenya Voucher Program for Training and Business Development Services." Africa Region Private Sector Group, Washington.D.C.: World Bank.

92. Roubaud, Francois and Merielle Razafindkoto (2007). "The Informal Sector in the LDCs: An Economic and Statistical Perspective," a powerpoint presentation in Bangkok.

93. Schneider, F. (2005). "The Informal Sector in 145 Countries.” Department f Economics, Linz University.

94. Schneider, F. (2007). "Shadow Economies and Corruption all over the World: New Estimates for 145 Countries." Economics: The Open Access, Open Assessments E Journal.

95. Schneider, F. (2002). "Size and Measurement of the Informal Economy in 110 Countries Around the World", Paper presented at the Workshop of Australian National Tax Centre, ANU, Canberra, Australia, July 17.

96. Schneider, F. and R. Klingrnair (2004). "Shadow Economies Around the World: What do we Know?", University of Link Department of Economics Working Paper, No.0403.

97. Sethuraman, S.V. (1997) "Informal Economy in Africa: the Emerging Development Challenge," Chapter 13 in ILO (1997) Africa's Informal Economy, ILO, Geneva.

98. Sparks, Donald (2008). "Electronic Payments in Sub Saharan Africa: Will Mobile Telephony Accounts Systems be the Next Leapfrog Technology for Development?", International Review of Business Research Papers, Volume 4, Number 1.

99. Tan, Hong (2006). "In-service Skills Upgrading and Training Policy: Global and Regional Perspective," Paper presented at the MNA Job Creation and Skills Development Conference, December 2005, Cairo.

100. United Nations (1996). Informal Sector Development in Africa, UN, New York.

101. United Nations Economic Commission for Africa (2001). Five Years after Beijing: What Efforts in Favour of African Women?, Addis Ababa, Ethiopia.

102. United Nations Economic Commission for Africa (2005) Economic Report on Africa 2005, Addis Ababa, Ethiopia.

103. Verick, Sher (2008). The Impact of Globalization on the Informal Sector in Africa. Economic and Social Policy Division, UNECA, Addis Ababa. 
104. Verner, Dorte and Mette Verner (2005). "Economic Impacts of Professional Training in the Informal Sector: the Case of the Labor Force Training Program in Cote d'Ivoire." World Bank Policy Research Working Paper No. 3668. Washington, D.C.: World Bank.

105. Vishwanath, T. (2001). "Informal economy: Safety Valve or Growth Opportunity," Paper presented at the Linking Work, Skills, and Knowledge: Learning from Survival and Growth International Conference, 1012 September 2001, Interlaken, Switzerland.

106. Walther, Richard (2006a). "Vocational Training in the Informal Sector: Report on the South Africa Field Survey," Working Paper No. 30, Department of Research, Agence Francaise de Devetappernertt; Paris.

107. World Bank (2009). Doing Business 2010, Washington, DC: World Bank.

108. World Bank (2001). World Development Report 2000/2001 - Attacking Poverty, Washington, DC: World Bank.

109. World Bank (2007). World Development Report 2007: Development and the Next Generation. Washington, D.C.: World Bank.

110. Xaba, J., Horn, P. and S. Motala (2002) "The Informal Sector in sub-Saharan Africa," ILO Working Paper on the Informal Economy, No.2002/10. 
NOTES 